\title{
Results of carrying out engineering and environmental surveys at design of small hydroelectric power station
}

\author{
B.M. Khuchunaev, A.A. Tashilova, L.A. Kesheva*, N.V. Teunova \\ Federal State Budgetary Institution High-mountain Geophysical Institute, 360030, Nalchik, \\ Russia
}

\begin{abstract}
Engineering and environmental surveys are one of types of the main engineering researches which are carried out for ecological justification of construction and other economic activity for the purpose of prevention, decrease or elimination of adverse environmental and related social, economic and other effects and also preservation of optimal conditions of life of the population. The purpose of engineering and environmental surveys is obtaining sufficient data on the existing state of environment around arrangement of a construction object (reconstruction). An object of research is the condition of the surrounding environment around placement of Verkhnebalkarskaya small hydroelectric power station.
\end{abstract}

\section{Introduction}

An important role in the design of construction objects has engineering-ecological researches surveys to assess the current state and forecast possible changes in the natural environment under the influence of anthropogenic pressure.

Engineering and environmental surveys along with other types of engineering surveys for construction must be carried out before making design decisions and before developing working design documentation, in order to create an appropriate information base (Building codes and regulations (BCR) 11-02-96, 1996; Set of rules (SR) 11-102-97, 1997; SR 11-103-97, 1997; SR 11-104-97, 1997; SR 11-105-97, 1997; SR 11-108-98, 1998; SR 11-109-98, 1998).

These documents have remained largely inoperative for decades. The situation changed after the entry into force of the Federal Law of December 18, 2006 No. 232FZ "On Amendments to the Urban Planning Code of the Russian Federation and Certain Legislative Acts of the Russian Federation" (Federal Law No. 232, 2006). The Urban Planning Code of the Russian Federation, in Article 47, fixed the need to perform engineering surveys for the preparation of project documentation, construction, and reconstruction of capital construction projects. The need to base on the results of engineering surveys is also foreseen in the preparation of territorial planning documents, land use and development rules, and territory planning documentation.

\footnotetext{
*Corresponding author: kesheva.lara@yandex.ru
} 


\section{Goals and objectives of engineering and environmental researches}

The tasks of engineering and environmental researches are determined by the peculiarities of the natural environment, the nature of existing and planned anthropogenic impacts, and vary depending on the stage of design and exploration work (Chizhov, 2009).

The assess of the state of the environment in the area of the Verkhnebalkarskaya small hydropower station (SHPS) is the subject of this research. The object is located in the Chereksky District of the Kabardino-Balkarian Republic, the main structures of the SHPS are projected on the terraces of the right bank of the r. Cherek Balkarsky (Fig. 1).

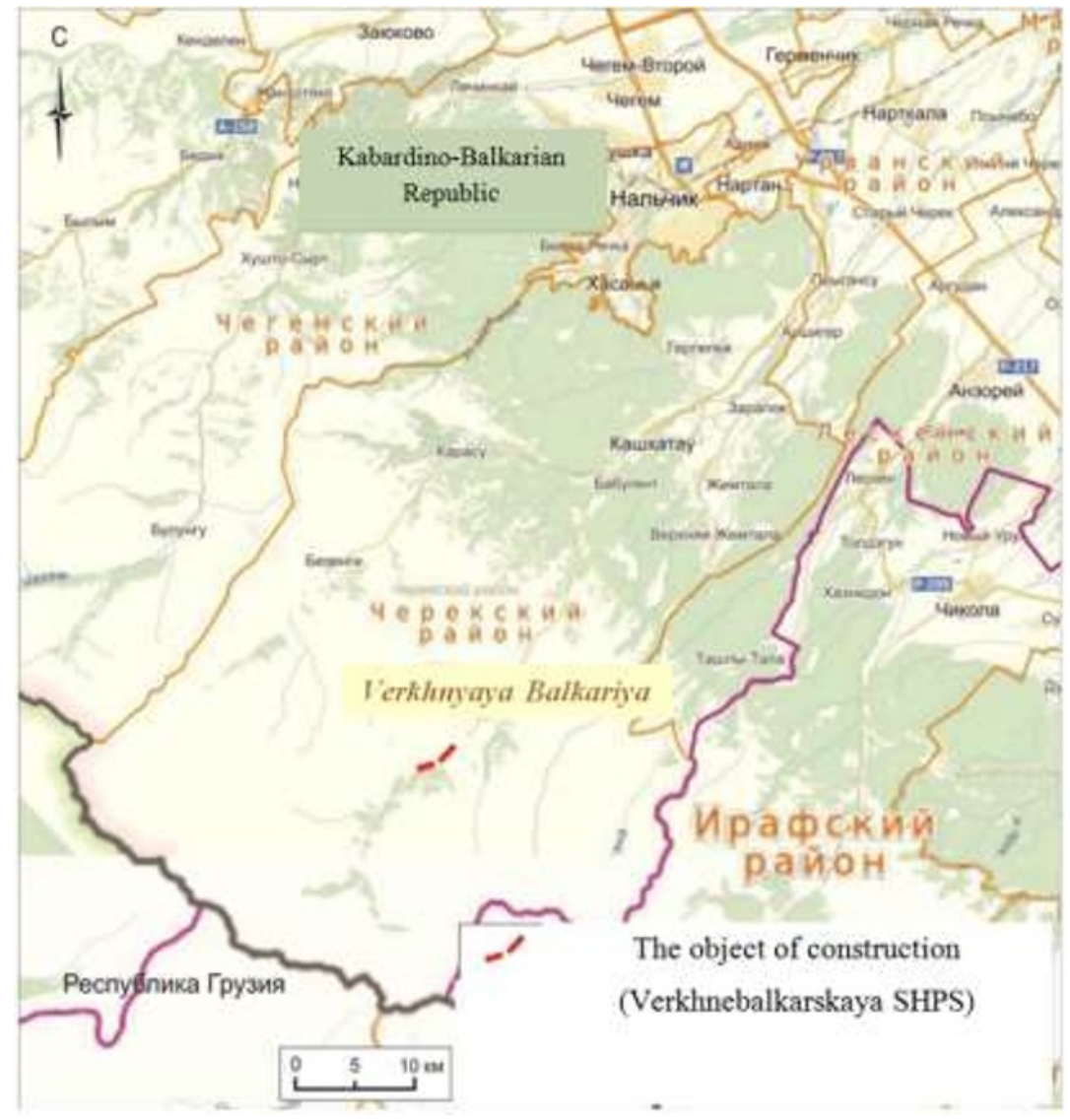

Fig. 1. Administrative-territorial location of the construction object

The total area of the survey is 29.0 hectares, the depth of the study of soils is up to $2.0 \mathrm{~m}$. The nearest residential area is located at a distance of more than $280 \mathrm{~m}$ in the north-east direction from the object (residential buildings for military families).

The tasks of engineering-ecological researches considered in this paper are:

- assessment of the current ecological state of the components of the environment;

- assessment of pollution of groundwater and surface water and soil cover;

- preparation of the preliminary forecast of possible environmental changes during the construction and operation of the designed object; 
- development of proposals and recommendations on the organization of environmental protection measures.

\section{Assessment of the study area survey}

The climate of the survey area is continental, moderately warm, characterized by winter cold with the presence of snow cover and warm, thundery summer. The average annual air temperature in the design area of Verkhnebalkarskaya SHPS is positive and is $5.9^{\circ} \mathrm{C}$. The average annual rainfall in the area under consideration is $600 \mathrm{~mm}$.

The survey area is agrarian and tourist, due to which there is no industrial impact on the atmosphere. The main sources of air pollution are mobile sources (road transport), natural gas boilers make a minor contribution.

The area of construction of the SHPP in terms of physical-geographical zoning is included in the zone of high-mountain deciduous forests of the Great Caucasus. In terms of altitudinal-belt structure, the study zone belongs to the Terek variant of the East Caucasian type of zonality (Kerefov and Fiapshev, 1977).

The relief of the area of the proposed construction of the Verkhnebalkarskaya SHPS is erosive-tectonic, which decreases in the northeast direction from $1370 \mathrm{~m}$ to $1200 \mathrm{~m}$.

There were mountain meadow soils, brown mountain forest soils and anthropogenically transformed soils on the territory of engineering and environmental surveys.

The vegetation of the Cherek district is rich and diverse. Seventy four Caucasian endemics were identified here, of which 54 species are endemic for the Central Caucasus, and 6 for the territory of Kabardino-Balkaria. The territory of the planned activity is located within the belt of forests and forest meadows.

The diversity of relief, vegetation and climate determines the diversity of the world of animals living in the Republic. In the CBD, there are 63 species of mammals, represented by 6 species of pedigree, 22 species of rodents, 9 species of insectivores, 10 species of bats, 10 species of predators. 15 species of reptiles, 7 species of amphibians, 10 species of fish are found. There are 316 species and subspecies of birds, of which 157 nest, 38 species arrive for wintering, 121 species occur during migration (Report, 2016).

\section{The current ecological state of the construction area}

To assess the current ecological state of the survey area, samples of groundwater and surface water and soil were sampled. Groundwater is one of the most important minerals and is of strategic importance as a reliable source of drinking water supply to the population. Groundwater samples were taken from 4 wells at a depth of 5 to 20.9 m.

As a result of the conditional comparative analysis of groundwater by chemical indicators with respect to permissible levels for surface waters of populated areas, water objects for household, drinking and community water use, excess sanitary and hygienic standards for total iron content in samples No. 1, 2 have been established (table 1). 
Table 1. The results of laboratory studies of groundwater samples

\begin{tabular}{|l|l|c|c|c|c|c|}
\hline № & \multicolumn{1}{|c|}{$\begin{array}{c}\text { Indicator } \\
\text { name }\end{array}$} & $\begin{array}{c}\text { Sample } \\
\text { №1, } \\
\mathrm{h}=14-15 \mathrm{~m}\end{array}$ & $\begin{array}{c}\text { Sample } \\
\text { №2, } \\
\mathrm{h}=7.0 \mathrm{~m}\end{array}$ & $\begin{array}{c}\text { Sample } \\
\text { №3, } \\
\mathrm{h}=5.0 \mathrm{~m}\end{array}$ & $\begin{array}{c}\text { Sample } \\
\text { №4, } \\
\mathrm{h}=20.9 \mathrm{~m}\end{array}$ & $\begin{array}{c}\text { Sanitation } \\
\text { Standard }\end{array}$ \\
\hline 1 & $\mathrm{pH}$, unit & 6.6 & 7.2 & 7.4 & 7.5 & $6.5-8.5$ \\
\hline 2 & Nitrite ions, $\mathrm{mg} / \mathrm{dm}^{3}$ & not found & not found & not found & not found & 3.3 \\
\hline 3 & Nitrate ions, $\mathrm{mg} / \mathrm{dm}^{3}$ & 5.0 & 5.0 & 5.0 & 1.0 & 45 \\
\hline 4 & Ammonium ion, $\mathrm{mg} / \mathrm{dm} 3^{3}$ & 0.2 & 0.1 & 0.1 & 0.7 & 1.5 \\
\hline 5 & Fe common, $\mathrm{mg} / \mathrm{dm}^{3}$ & 0.5 & 0.5 & 0.3 & 0.3 & 0.3 \\
\hline 6 & Chlorides, $\mathrm{mg} / \mathrm{dm}^{3}$ & 1.8 & 3.6 & 1.8 & 3.6 & 350 \\
\hline 7 & Sulfates, $\mathrm{mg} / \mathrm{dm}^{3}$ & 21.1 & 17.0 & 14.1 & 10.4 & 500 \\
\hline 8 & Mg, mg / dm & 1.2 & 3.6 & 4.9 & 7.3 & 50 \\
\hline 9 & Ca, mg / dm & 14.0 & 14.0 & 50.1 & - \\
\hline 10 & $\begin{array}{l}\text { Dry residue } \\
\text { (mineralization) }, \mathrm{mg} / \mathrm{dm}^{3}\end{array}$ & 90 & 96 & 93 & 215 & 1000 \\
\hline
\end{tabular}

Considering that the groundwater in the survey area is not a source of drinking, household and recreational water use, the use of these standards is informational and serves to assess the anthropogenic load.

In order to assess the quality of natural surface water in the area of the object, sampling and laboratory studies of 4 samples were carried out by chemical indicators from the Cherek Balkarsky river and from the untitled watercourse. From the table 2 it can be seen that in the samples of water exceeding the permissible levels for the studied normalized parameters and ingredients was not detected.

Table 2. Laboratory test results for surface water samples by chemical indicators and ingredients

\begin{tabular}{|c|c|c|c|c|c|c|}
\hline № & Ingredient & $\begin{array}{l}\text { Sample } \\
\text { №1 }\end{array}$ & $\begin{array}{l}\text { Sample } \\
\text { №2 }\end{array}$ & $\begin{array}{l}\text { Sample } \\
\text { №3 }\end{array}$ & Sample №4 & $\begin{array}{l}\text { Sanitation } \\
\text { Standard }\end{array}$ \\
\hline 1 & $\mathrm{pH}$, unit & 7.7 & 7.7 & 7.7 & 7.7 & $6.5-8.5$ \\
\hline 2 & $\mathrm{COD}, \mathrm{mg} / \mathrm{dm}^{3}$ & 23.5 & 23.0 & 11.0 & 6.0 & 30.0 \\
\hline 3 & $\mathrm{BOD} 5, \mathrm{mg} / \mathrm{dm}^{3}$ & $<1.0$ & $<1.0$ & 1.2 & 1.2 & 4.0 \\
\hline 4 & $\begin{array}{l}\text { Suspended substances, } \\
\mathrm{mg} / \mathrm{dm}^{3}\end{array}$ & $<10.0$ & $<10.0$ & $<10.0$ & $<10.0$ & $\begin{array}{c}0.75 \text { to } \\
\text { background }\end{array}$ \\
\hline 5 & Oil products, $\mathrm{mg} / \mathrm{dm}^{3}$ & $<0.01$ & $<0.01$ & $<0.01$ & $<0.01$ & - \\
\hline 6 & Nitrite ions, $\mathrm{mg} / \mathrm{dm}^{3}$ & $<0.05$ & $<0.05$ & $<0.05$ & $<0.05$ & 3.3 \\
\hline 7 & Nitrate ions, $\mathrm{mg} / \mathrm{dm}^{3}$ & 1.05 & $<1.0$ & 1.35 & 1.53 & 45.0 \\
\hline 8 & Ammonium, mg / $\mathrm{dm}^{3}$ & 0.14 & 0.16 & 0.16 & 0.11 & 1.5 \\
\hline 9 & Fe common, $\mathrm{mg} / \mathrm{dm}^{3}$ & 0.1 & 0.2 & 0.2 & $<0.1$ & 0.3 \\
\hline 10 & Cuprum, mg / dm ${ }^{3}$ & $<0.001$ & $<0.001$ & $<0.001$ & $<0.001$ & 1.0 \\
\hline 11 & Zinc, $\mathrm{mg} / \mathrm{dm}^{3}$ & 0.014 & 0.001 & 0.001 & 0.003 & 1.0 \\
\hline 12 & Nickel, mg / dm ${ }^{3}$ & 0.001 & $<0.001$ & 0.001 & $<0.001$ & 0.02 \\
\hline 13 & Manganese, $\mathrm{mg} / \mathrm{dm}^{3}$ & 0.016 & 0.02 & 0.019 & 0.001 & 0.1 \\
\hline 14 & Chlorides, $\mathrm{mg} / \mathrm{dm}^{3}$ & $<10.0$ & $<10.0$ & $<10.0$ & $<10.0$ & 350 \\
\hline 15 & Sulfates, $\mathrm{mg} / \mathrm{dm}^{3}$ & 23.2 & 17.5 & 21.0 & $<10.0$ & 500 \\
\hline 16 & Phenols, $\mathrm{mg} / \mathrm{dm}^{3}$ & $<0.0005$ & $<0.0005$ & $<0.0005$ & $<0.0005$ & 0.001 \\
\hline 17 & $\begin{array}{l}\text { Dry residue } \\
\text { (mineralization), } \mathrm{mg} / \\
\mathrm{dm}^{3}\end{array}$ & 83 & 67 & 60 & $<50.0$ & 1000 \\
\hline 18 & $\begin{array}{l}\text { Common phosphorus, } \\
\mathrm{mg}^{-\mathrm{dm}^{3}}\end{array}$ & $<0.025$ & $<0.025$ & $<0.025$ & $<0.025$ & - \\
\hline 19 & $\begin{array}{l}\text { Dissolved oxygen, } \mathrm{mg} \\
/ \mathrm{dm}^{3}\end{array}$ & 11.0 & 10.7 & 11.0 & 10.9 & No less 4 \\
\hline
\end{tabular}


The soil is the depositing medium of man-made chemicals and a factor in the transmission of infectious and parasitic diseases, that can have an adverse effect on the living conditions of the population and its health. Important hygienic importance for creating favorable living conditions for the population is the sanitary condition of populated areas and the degree of soil contamination.

Occupying a central place in the biosphere and being the initial link of all food chains, contaminated soil can become a source of secondary pollution of atmospheric air, water bodies, groundwater, food of plant origin and animal feed, and thereby affect the ecological and hygienic situation in general. Vehicle emissions, construction and road dust, unauthorized landfills are the main sources of soil contamination in the survey area. The works consisting of an environmental survey of the soil of a land plot by chemical, microbiological, sanitary-parasitological, toxicological, and radiological indicators, determining the level of soil contamination based on the results obtained, were carried out to assess the quality of the soil. In accordance with clause 8.4.13 [SP $47.13330,2012]$, the study and general assessment of the sanitary condition of the soil (soils) is carried out on the basis of the requirements (Sanitary-epidemiological rules and regulations (SRR) 2.1.7.1287-03, 2003). In accordance with (Methodical instructions (MI) 2.1.7.730-99, 1999), the main criterion for the hygienic assessment of soil pollution by chemical substances is the maximum permissible concentration (MPC) or the approximately permissible concentration (APC) of chemical substances in the soil. For the analysis 24 samples were taken from the depth of 0.0-0.2 m. According to the results of the analysis, it was found that only in 3 samples the concentrations of arsenic, plumbum, cadmium, zinc, cuprum, nickel, hydrargyrum, benzo(a)pyrene do not exceed the allowable values. The maximum permissible concentration (MPC) in arsenic content is observed from 1.7 to 5.85 times in 21 samples. The concentration of zinc exceeds the norm 1.13-1.73 times in 11 samples. There is also an excess of cadmium and lead in 6 samples to the level of 1.1-2.34 times and 1.06-1.37 times, respectively. In accordance with (State standard (SS) 17.5.3.0584,1984 ), the fertile soil layer should not contain radioactive elements, heavy metals, residual quantities of pesticides and other toxic compounds in concentrations exceeding the maximum permissible levels established for the soil. Based on the above, the soil of the survey site in accordance with (SS 17.5.3.06-85, 1985; SS 17.5.1.03-86, 1986), removing and using the soil as a fertile layer for land plots of unproductive land (fertility increase) is not recommended.

Soils can be used for technical reclamation and vertical planning of the territory in accordance with recommendations on the use of soils in the Section V (SRR 2.1.7.1287-03, 2003).

\section{Conclusion}

During construction work possible sources of pollution of surface and ground waters may be unpurified surface wastewater from coatings; oil strait.

It is necessary to work in a strictly designated area to reduce the adverse effects on the aquatic environment. Washing of construction equipment and vehicles should be carried out in strictly designated areas equipped with sewage treatment plants.

The main sources of impact on soil cover during construction are motor vehicles and construction equipment, as well as waste generated during construction, temporary linear and site structures (temporary roadways, temporary construction base sites), permanent linear and site structures.

To reduce the negative impact on land in the period construction should include:

- the use of special access roads during transportation of raw materials; 
- preventing contaminants from reaching the ground surface;

- the admission to work of construction cars in a technical good condition, excluding leakage of fuel and oils;

- parking of construction vehicles are allowed only on site with hard coating, where the collection of contaminants is carried out followed by their export.

Reclamation of disturbed lands should be carried out after construction work.

\section{References}

1. BSR 11-02-96. Engineering surveys for construction. General provisions, Gosstroy of Russia, Moscow, 1996.

2. SR 11-102-97. Engineering and environmental surveys for construction, Gosstroy of Russia, Moscow, 1997.

3. SR 11-103-97. Engineering and hydrometeorological surveys for construction, Gosstroy of Russia, Moscow, 1997.

4. SR 11-104-97. Engineering and geodetic surveys for the construction of Gosstroy of Russia, Moscow, 1997.

5. SR 11-105-97. Engineering and geological surveys for construction. Part 1. General rules for the production of works, Gosstroy of Russia, Moscow, 1997.

6. SR 11-108-98. Survey of water sources based on groundwater, Gosstroy of Russia, Moscow, 1998.

7. SR 11-109-98. Survey of ground construction materials, Gosstroy of Russia, Moscow, 1998. - 28 p.

8. The Federal Law "On Amendments to the Town Planning Code of the Russian Federation and Certain Legislative Acts of the Russian Federation" of December 18, 2006 No. 232-Ф3, Russian Newspaper. 2006. 23 Dec.

9. N.A. Chizhov, Engineering surveys, 11, 26-32 (2009).

10. K.N. Kerefov, B.Kh. Fiapshev, Natural zones and belts of the KabardinoBalkarian Autonomous Soviet Socialist Republic, Nalchik, 1977.

11. Report on the state and protection of the environment of the Kabardino-Balkarian Republic in 2016. Department of Natural Resources and Ecology of the CBD, Nalchik, Print Center publishing house.

12. SR 47.13330.2012 "Engineering surveys for construction. The main provisions. Updated edition of SNiP 11-02-96".

13. SRR 2.1.7.1287-03 "Sanitary and epidemiological requirements for soil quality".

14. MI 2.1.7.730-99 "Hygienic assessment of soil quality in populated areas".

15. SS 17.5.3.05-84 "Nature Conservation. Land reclamation. General requirements for land".

16. SS 17.5.3.06-85 "Nature Conservation. Soils. Requirements for the determination of norms of removal of the fertile layer of soil in the production of earthworks"

17. SS 17.5.1.03-86 "Nature Conservation. Soils. Classification of overburden and host rocks for biological land reclamation". 